\title{
A mindfulness és liminalitás felértékelődése: spirituális elvonulási központok, a fenntartható jövő desztinációi?
}

\author{
Szerzők: Lengyel Attila
}

\begin{abstract}
A globális szocio-ökológiai válság mélyülésével párhuzamosan felértékelődik a desztinációk belső transzformációt katalizáló liminális jellege. A liminális potenciál aktualizálódásának és így az ennek nyomán megvalósuló belső transzformációnak is alapfeltétele az éber, nyitott jelenlét, a tudatosság és a figyelem, amit mindfulness néven ismer a szakirodalom. A belső transzformáció igénye a fenntarthatóság kontextusában nagy jelentôségú, mivel a jelenkori válság nem elsődlegesen tudományos-technikai kihivás, hanem alapvetóen egzisztenciális problematika. A spirituális elvonulási központok fókuszáltan jelenítik meg a desztinációs térre generálisan jellemzô liminális potenciált, vagy heideggeri terminológiával élve, Spielraum jelleget. A spirituális elvonulási központ transzformációt fokozottan katalizálni képes jellege kiemeli a desztinációt a turizmust ma még dominánsan jellemző, hedonista motivációkra és eszkapizmusra épülö, fogyasztást kiszolgáló szerepkörből és helyette annak spirituális jellegét, transzformatív potenciálját emeli a középpontba. Turizmusszociológiai szempontból az elvonulási központok témaköre eddig szinte érintetlen terület a magyar nyelvú szakirodalomban. A cikk célja a döntéshozók figyelmének felhívása a téma fontosságára.
\end{abstract}

Kulcsszavak: spirituális elvonulási központ, mindfulness, liminalitás, transzformáció, autentikus létmód.

\section{Bevezetés}

A spirituális elvonulási központok (továbbiakban SEK-ek) jelentôségének megértéséhez, egyfelől át kell érezni és meg kell érteni a jelenkori szocio-ökológiai krízis súlyosságát, másrészről tisztázni kell, hogy milyen okok állnak a krízis hátterében, és ezek hogyan szüntethetők meg. A COP2 $21^{2}$ konferencia Párizsban, bár céljaiban ambiciózus, operatív szempontból kudarc. Ahogyan a CIVIL SOCIETY REVIEW ${ }^{3}$ (HOLZ et al. 2018) rámutat, a kumulatív emisszióért elsődlegesen felelôs fejlett ipari országok által tett önkéntes emiszsziócsökkentési vállalások történelmi felelősségükhöz és cselekvési potenciáljukhoz képest messze elmaradnak az elvárhatótól. Ezen túl, az eddig tett

\footnotetext{
${ }^{1}$ egyetemi tanársegéd, Neumann János Egyetem, lengyel.attila@gk.uni-neumann.hu

21992 óta a 21. globális klímacsúcs, amit Párizsban rendeztek 2015-ben. Az országok részéről benyújtott konkrét emissziócsökkentési vállalások miatt mérföldkőnek tekintik.

${ }^{3}$ Civil kezdeményezés, melynek célja a Párizsi Klímaegyezmény keretében tett önkéntes emissziócsökkentési célok felülvizsgálata, kritikája és az igazságos tehervállalásra vonatkozó javaslatok kidolgozása.
}

összes felajánlás nem elég ahhoz, hogy a Párizsban célként kitűzött és a klímatudósok által régóta javasolt $1,5-2{ }^{\circ} \mathrm{C}$ hőmérséklet emelkedésen belül maradhassunk az elkövetkezendó évtizedekben. LÁNYI ANDRÁS néhány éve megfogalmazott kérdése „Hogyan lehetséges az, hogy egy mindenki által ismert, feltartóztathatatlanul közeledő katasztrófa elhárítása érdekében gyakorlatilag semmi sem történik?" (LÁNYI 2013: 823) sajnos még mindig időszerú. Ugyanakkor az igazán nagy kérdés nem ez. Egyéb diszciplínák mellett a pszichológia, a szociológia és az antropológia, számos magyarázattal szolgált arra, hogy kritikus helyzetekben (még ha mindenki által ismert is a helyzet kritikussága) miért nem cselekszenek érdemben az egyének és a közösségek (GIFFORD 2011). A fontosabb kérdés a következő: Hogyan lehet elérni, hogy megváltozzon, fenntarthatóvá váljon az emberek világszemlélete, értékrendje és viselkedése? A cikk szempontjából lényeges turisztikai parafrázis így hangzik: Hogyan tud a turizmus segíteni abban, hogy megváltozzon, fenntarthatóvá váljon az emberek világszemlélete, értékrendje és viselkedése?

A turizmus különösen ellentmondásos része a globális fenntarthatósági kihívásnak. LENZEN és szerzótársai (2018) szerint 2013-ban 8\% körüli volt a globális emisszióból való részesedése. Mivel 2013- 2017 között 22\%-al nőtt a turista- 
érkezések száma, és nem történt érdemi emiszsziócsökkentés a szektorban, az érték ma valószínúleg jóval 10\% fölött van. Az iparág egyre karbon-intenzívebb természetét és a növekedési kilátásokat figyelembe véve 2050-re ez az érték akár 40\%-ra (!) is felmehet (DUBOIS-CERON 2006, GÖSSLING-PEETERS 2007). Miközben tagadhatatlanul számos erőfeszítés történt és történik azért, hogy a turizmust, mely ma a világ talán legdinamikusabban fejlődő iparága, a kínálati és a keresleti oldalon is környezettudatosabb gondolkodás és cselekvés jellemezze, számos kutató szerint a szektor a profitmaximalizálásra épülő, fenntarthatatlan globális kapitalizmus (SHUTT 1998) zászlóshajója és jelentốs mértékú strukturális erőszakért felelós (BÜSCHER-FLETCHER 2017). Az ökológiai gondolkodás mellett (DÁVID 2011), ehhez kapcsolódóan merül fel egyre nagyobb hangsúllyal az utazás és a turisztikai tér liminális jellege, belső transzformációt katalizálni képes potenciálja, mint a turizmus jelen helyzetben talán legértékesebb attribútuma (REISINGER 2013, KIRILLOVA et al. 2017b). A belső transzformáció igénye a fenntarthatóság kontextusában nagy jelentőségú, mivel a jelenkori válság nem elsôdlegesen tudományos-technikai kihívás, hanem alapvetốen egzisztenciális problematika, melynek hosszú távú megoldása a jelenlegi (túl) fogyasztói paradigma sürgós meghaladását feltétele$z i$ (ZSOLNAI 2010). Ez az egyén szintjén csak egy olyan belső transzformáció révén lehetséges, melyben a fogyasztói gépezet vágy-szerzés dialektikáját felválthatja egy elsődlegesen eudaimonikus jóllétet a középpontba emelő, spirituális alapokon nyugvó életstílus (DIENER et al. 2009, MARTOS 2010). Jelen írásban a transzformáció és az ennek nyomán kialakuló autentikus létmód kérdése elválaszthatatlan az ember-ember közti morális és az ember-környezet közötti környezeti etikai szempontoktól. A SEK-ek fókuszáltan jelenítik meg a desztinációs térre generálisan jellemzó liminális potenciált, vagy heideggeri terminológiával élve, Spielraum jelleget. A SEK-ek transzformációt fokozottan katalizálni képes jellege (HEINTZMAN 2013, KIRILLOVA et al. 2017b) kiemeli a turizmust a ma még dominánsan jellemző, hedonista motivációkra és eszkapizmusra épülő (VIDON-RICKLY 2018), fogyasztást kiszolgáló szerepkörből, és helyette annak spirituális jellegét, transzformatív potenciálját emeli a középpontba. Ezt hangsúlyozza REISINGER (2013), megállapítva, hogy a transzformatív potenciál a turizmus legértékesebb sajátsága és felveti a kérdést, miként tudna a transzformatív turizmus hozzájárulni a globális fenntarthatósághoz.

\section{Az elvonulás vallási és filozófiai háttere}

A turizmus piacán ma megjelenő SEK-ek eszmei és spirituális előképe a nagyobb vallásokban hoszszú idôre visszanyúló intézmény (MERTON 1999). Az elvonulás, bár sokféle formát ölthet, a szó jelentésének megfelelóen a hétköznapi közegtól és közösségtől való önkéntes, vagy a vallás szabályai által elóírt eltávolodást, egyéni elmélyülést jelent. $\mathrm{Az}$ angol nyelvú turisztikai szakirodalomban használt retreat szó latin eredetú, jelentései között megtaláljuk a következőket: „hátrébb lépés”, „valamilyen tevékenység abbahagyása”, „visszahúzódás", "extremitásokkal való felhagyás". nulás alatti elmélyülés a teista vallások (például judaizmus, kereszténység, iszlám, hinduizmus) esetén elsódlegesen az istennel való kapcsolat elmélyítését jelenti, míg az olyan alapvetôen meditáció alapú, nem teista vallásnál, mint a buddhizmus, a meditáció tökéletesítése áll a gyakorlás középpontjában. Ugyanakkor a meditatív hagyományok belső elcsendesedése több monoteista vallás misztikus-ezoterikus irányzatánál is megjelenik (EIFRING 2013).

A transzformatív indíttatásból történő elvonulás elóképe a kereszténységen belül Jézus negyven napos böjtje a sivatagban. Jézus a következőt mondja az elvonulásról: „,Te pedig amikor imádkozol, menj be a belsô szobádba, és ajtódat bezárva imádkozzál Atyádhoz titokban." (MAGYAR BIBLIATÁRSULAT 2018, MT. 6:6). Ahogyan Richard ROHR ferences szerzetes is rámutat, ez a „belső szoba" nem fizikálisan értendô, hanem arra a belső elvonulásra és elcsendesedésre utal, amit a meditatív hagyományok belső gyakorlatai is megcéloznak (ROHR 2012). Gautama Sziddhárta hat évet töltött elvonulva erdei aszkéták között totális önsanyargatásban, eredmény nélkül. Ezután Bodh-Gajában egy fügefa (a Bódhi fa) alatt ülve tudatának mélységeibe vonult vissza és egyetlen éjszaka alatt megvilágosodott (PIYADASSI 1998). A Buddha az elvonulásról és az állandó úton levésről így beszél később egy tanítványának: „Aggivesszana, még felébredésem előtt, felébredésre törekvő bódhiszattvaként így gondolkodtam: az otthoni élet zsúfoltság és poros út, a vándorélet szabad ég, nem könnyú az otthon élónek a tökéletesen teljes és tiszta, feddhetetlen jámborság útját járni. Így hát megválok hajamtól és szakállamtól, megsárgult ruhát öltök és az otthonból az otthontalan vándorlétbe távozom." ${ }^{5}$ Bár a kereszténység és a buddhizmus sok és lényeges ponton különbözik, az elvonulás aktusa mindkét alapítónál kulcsmomentum. Az iszlám misztikus

\footnotetext{
${ }^{4} \mathrm{https}: / / \mathrm{www} . e t y m o n l i n e . c o m /$ search?q=retreat

${ }^{5} \mathrm{http}: / / a-b u d d h a-u j j a . h u / S z u t t a / M a j j h i m a-36-c s 1$
} 
Lektorált tanulmányok

irányzatában, a szufizmusban, az elvonulás neve khalwa. Jézus és a Buddha elvonulásához hasonlóan Mohamed is keresztül megy ezen a belső megtisztulási fázison, mikor elvonul a Hira hegy egyik barlangjába imádkozni. Az imádság elvonulást feltételező individualizált formája a judaizmusban a XIII. századig nem volt jellemző. A század végén Ábrahám Abulafia alapította meg a Prófétikus Kabbalizmust, amelyben a judaizmus, és ezen belül a kabbalizmus, történetében először lett az istennel való misztikus egyesülés (unio mystica) leginkább javasolt formája az egyéni elvonulás (hitbodedut).

Az elvonulás mozzanata az egzisztencialista filozófusoknál is hangsúlyos. Ennek a relevanciája jelen cikk szempontjából az, hogy a transzformációval és autentikus létmóddal foglalkozó turisztikai szakirodalomban a szerzők előszeretettel adaptálják át egzisztencialista filozófusok (fóként Heidegger, Kierkegaard, Sartre) koncepcióit a turisztikai kontextusra (STEINER-REISINGER 2006, BROWN 2013). Kirkegaard értelmezésében a tömegből való visszavonulás alapfeltétele annak, hogy az ember élete autentikus értelmet nyerjen (OBINYAN 2014). HEIDEGGER (1962) Lét és idố címú grandiózus munkájában az inautentikusból az autentikus létbe vezetô transzformáció feltételeként jelölte meg, hogy a tömegben (das Man) feloldódott és egyéniségét vesztett emberi lény (Dasein) felismerje állapotát, és a tömegből „,viszszavonulva" nézzen szembe a ténnyel, hogy saját sorsáért egyedül ő a felelős. Az elvonulás általában sem a vallásokban (a remeteség, aszketizmus vagy a buddhizmus számos formája kivétel lehet), sem pedig az egzisztencialista filozófusoknál nem jelenti azt, hogy az egyén végleg kivonul a társadalomból. Az elvonulás liminális periódus, ami olyan transzformáció lehetőségét hordozza magában, melynek révén az egyén értékesebb szerepet tud betölteni a közösségben.

\section{Mindfulness-liminalitás- transzformáció-autentikus létmód}

A turisztikai szakirodalomban szinte kizárólag a LANGER (1989) féle szocio-kognitív mindfulness (a továbbiakban SZKM) koncepciója került feldolgozásra (MOSCARDO 1996, FRAUMANNORMAN 2004). Az SZKM egy új, információra nyitott, azt kritikusan és kontextuálisan értékelni tudó kognitív állapot, melyet LANGER (1993:44) így jellemez: ,... olyan tudatállapot, ami a kontextusra való szenzitivitás, az információk új szemszögből történô megvizsgálása nyomán áll eló ...". MOSCARDO (1996) az épített örökséget látogató turisták élményei kapcsán adaptálta ezt a LANGER féle kon- cepciót a turisztikai kontextusra. Arra hívja fel a figyelmet, hogy amennyiben a látogató úgy érzi, kontrollálhatja a történéseket, ahol a történések interaktívak és változatosak, akkor ez magasabb szintú SZKM-t indukálhat, melynek nyomán a turista gazdagabb élményeket szerez, és sokkal inkább tudja értékelni és óvni az értékes környezetet. A meditatív mindfulness (továbbiakban MM) éber figyelem és tudatosság, teljes jelenlét egy adott pillanatban, a tudatra való tudatosság. Nevezhetjük a tudat tudományának vagy a belsố csend múvészetének. Olyan relaxált, kitisztult, elcsendesedett, ugyanakkor nagyon éber tudatállapot, amikor az ember ítélkezésmentesen képes szemlélni bármit (gondolat, kép, érzés, szenzoriális ingerek), ami a tudatában felmerül (Vipassana technikák), ugyanakkor képes tudatát intencionálisan is fókuszálni (Samatha technikák). Amennyiben a tudat információval túlterhelt, kaotikus, robotpilóta (mindless) üzemmódban múködik (LANGER et al. 1978, BROWN-RYAN 2003), tehát nem sikerül az MM állapot megfeleló szintú elérése, így az SZKM sem valósulhat meg (LENGYEL 2018). Turisztikai kontextusban ez azt jelenti, hogy a turista addig nem tud igazán új információt befogadni, és nem tudja azt kreatívan manipulálni (SZKM), amíg a fejében az otthoni dolgok és beidegzódések zakatolnak. Amíg a tudatát nem csendesíti le és üríti $\mathrm{ki}, \mathrm{az}$ nem tud befogadó közegként funkcionálni. Ebből következóen az MM az SZKM ontológiai alapjaként is értelmezhető (LENGYEL 2018).

A mindfulness állapotában válik lehetségessé, hogy tudatilag ",hátralépve" nézzünk rá magunkra, a világra, és ráébredjünk, hogy igazi valónk, autentikus énünk több, mint azok a gondolatok, érzelmek, szerepek, amikkel hosszabb-rövidebb idôre azonosulunk (BHIKKHU et al. 1995). LYNN és szerzőtársai (2017) tesznek először határozott elvi különbséget a kétféle mindfulness között, és kvalitatív kutatási eredményeik alapján elemzik azok hatását a turisztikai térben szerzett élményekre. LENGYEL (2015) elsőként hívta fel a figyelmet arra, hogy a turisztikai tér különlegesen alkalmas az MM-mel való ismerkedésre, valamint arra, hogy az MM-re alapozott turisztikai termékek különlegesek, mert „hordozhatók”, hazavihetók és otthon tovább használva pozitív hatással lehetnek a fenntartható viselkedésre.

A mindfulness több évtizedes klinikai tesztelése nyomán mára nyilvánvaló, hogy az MM akár már rövid gyakorlás után is szignifikáns agystruktúrabeli, tudati, pszichés és szomatikus változásokat tud okozni (DAVIS-HAYES 2011, DE VIBE et al. 2017). Különösen fontos, hogy az empirikus eredmények alapján a magasabb mindfulness szint (LENGYEL 2017) és a fenntarthatóbb attitúd és viselkedés között szignifikáns pozitív kapcsolat 
van a globális fenntarthatóság (LENGYEL 2018, WAMSLER-BRINK 2018) és a turisztikai fenntarthatóság tekintetében is (CHAN 2018).

A spiritualitás, a transzformációhoz vagy autentikussághoz hasonlóan, sokféle jelentéssel „terhelt" kifejezés a turisztikai irodalomban és azon kívül is. Jelen írásban a spiritualitás egy olyan, vallási beállítottságtól független irányultság és gyakorlat, aminek célja a „belső hazatalálás”. Ennek a belső útkeresésnek a legradikálisabb formája az a teljes önfeladás, minden teljes elengedése, amit az MM technikák céloznak meg. A teljes belsô csendben jelenlévő éber tudatosság, az emberiség kulturális kontextustól független közös belső platformja. Nincsen szufi belsó csend, buddhista belső csend vagy keresztény belső csend, csak belső csend van. Ezt a fajta univerzális „interspiritualitást" fogalmazza meg TEASDALE (2010:133) a meditatív imádsággal összefüggésben: "Mélységes békét, csendet, nyugalmat és frissességet érzünk. Ebben a belsô csendben tapinthatóvá válik az isteni jelenlét." WAYNE TEASDALE katolikus szerzetesként sokat tett a vallások közötti párbeszédért, és ahogyan az idézetból egyértelmú, a buddhizmus meditációra épülő spiritualitása jelentősen hatott saját keresztény hitéletére.

A turisztikai tér liminális jellegével a külföldi szerzók közül sokan foglalkoztak már (ANDREWS-ROBERTS 2012, PRITCHARDMORGAN 2006). A hazai turizmusszociológiai szakirodalomban a RÉGI, RÁTZ és MICHALKÓ (2017) szerkesztette „Turizmus és transzformáció" c. tanulmánykötet hiánypótló. A kötetben MITEV és szerzótársai (2017) a vallási turizmus kontextusában elemzik a turisztikai tér liminális jellegét. A szó etimológiáját vizsgálva a latin limen szóhoz jutunk, ami „határpontot”, „küszöböt” jelent ${ }^{6}$. A liminális potenciált hordozó tér nevezhető küszöb/köztes térnek. Heidegger térmetaforával „Spielraum"-nak, tükörfordításban játéktérnek, hívja azt az egzisztenciális és metafizikai értelemben vett teret, ahol az emberi lény (Dasein) szabadon megnyilvánulhat (WRATHALL 2013). A kifejezés egybecseng azokkal a magyarázatokkal, melyek az utazás legfőbb pull motivációját az „elveszett paradicsom”, azaz a gondtalan, játékkal teli gyermeki lét újra megtalálásában jelölik meg (DANN 1996). A liminalitás rövid definíciójában TURNER (1974:59) is utal a liminalitás és a játék kapcsolatára: "A liminalitás a szakrális tér-idôben történó komplex események sorozata, melynek részét képezhetik a megszokottat felforgató és a ludikus események is.". A liminalitás a turisztikai térben (és bármely más térben) csupán szunnyadó potenci-

$\overline{6 \mathrm{https}: / / \mathrm{www} . e t y m o n l i n e . c o m / \text { search? }} \mathrm{q}=$ liminal ál. Az aktualizált liminalitás, vagy köztes térben való létmód, ami a transzformáció lehetőségét is hordozza, az egyén és a turisztikai tér szinergizáló interakciójából áll elő. Ha egy turista a Taj Mahal előtt állva folyamatosan posztolgat a facebookra, cseveg a mobilján, vagy csak állandó belsó dialógust folytat magával, azaz nincs igazán jelen, alacsony az MM szintje, akkor az erős liminális potenciállal bíró turisztikai tér deszakralizálódik, nem tud aktuális liminális térré válni. Ugyanakkor, ha egy nyaraló a Costa Brava homokjában fekve teljes éberséggel átadja magát a tenger morajlásának, akkor az egyébként tömegturisztikai tér is liminális térré alakulhat. Bármilyen tér lehet liminális. Az ember az, aki nyitott, befogadó, éber jelenlétével (mindfulness) szakralizálhat, illetve ennek ellentétével, a jelen nemlétével (mindlessness) deszakralizálhat bármilyen teret vagy történést. Ha nagyfokú mindfulness-szel van jelen a turisztikai térben, akkor az erre az állapotra fokozottan jellemzó kiüresedés, befogadó attitúd, a pillanatban való éber és teljes jelenlét megteremti a liminalitás lehetőségét, hogy a turisztikai élmény transzformatívvá válhasson. Érvényesülhetnek azok a transzformációt elindítani képes faktorok, melyekre KIRILLOVA és szerzôtársai (2017a) utalnak a témáról írt cikkükben. Ilyen például: egység a természettel, egy másik személlyel vagy személyekkel, introspekció, saját határok feszegetése, esztétikai élmény, spontán történő szokatlan dolgok. Az alcímben megjelenő mindfulness-liminalitás-transzformáció-autentikus létmód oksági láncolat, melyben a mindfulness az utána következó elemeknek előfeltétele. Felmerül a kérdés: ha minden tér, minden történés lehet liminális, akkor miért nem használja mindenki az otthoni közeget transzformációra, ezzel is csökkentve az utazásból adódó környezetterhelést? Analógiaként gondolhatunk a gyakorlott és kezdő meditálókra. Egy gyakorlott meditálónak teljesen mindegy, hogy egy zsúfolt nagyvárosban sétál, vagy egy csendes tisztáson üldögél. A kezdő meditálótól azt várni, hogy a káosz közepén vagy akár a hétköznapi környezet „robotpilóta üzemmódot" előhívó körülményei között állandóan éber, meditatív állapotban maradjon, értelmetlen. A turisztikai tér (ahogy az erdei tisztás) magas liminális potenciállal bír, ami segítheti a transzformáció beindulásához szükséges küszöbállapot elérését. Amennyiben az utazás magas ökológiai lábnyomot hagy, a helyzet mindenképpen paradox. Ugyanakkor JAIMANGAL-JONES és szerzőtársai (2010) rámutatnak, hogy a liminalitás nem feltétlenül áll egyenes arányban a desztináció távolságával. Mivel a SEK-ben lehetôség van a liminalitás tárgyi környezetbe és szolgáltatásokba foglalt megtervezésére, a „fenntartható utazás vagy 
Lektorált tanulmányok

A mindfulness és a turisztikai tér liminalitásának hatása a fenntarthatóságra

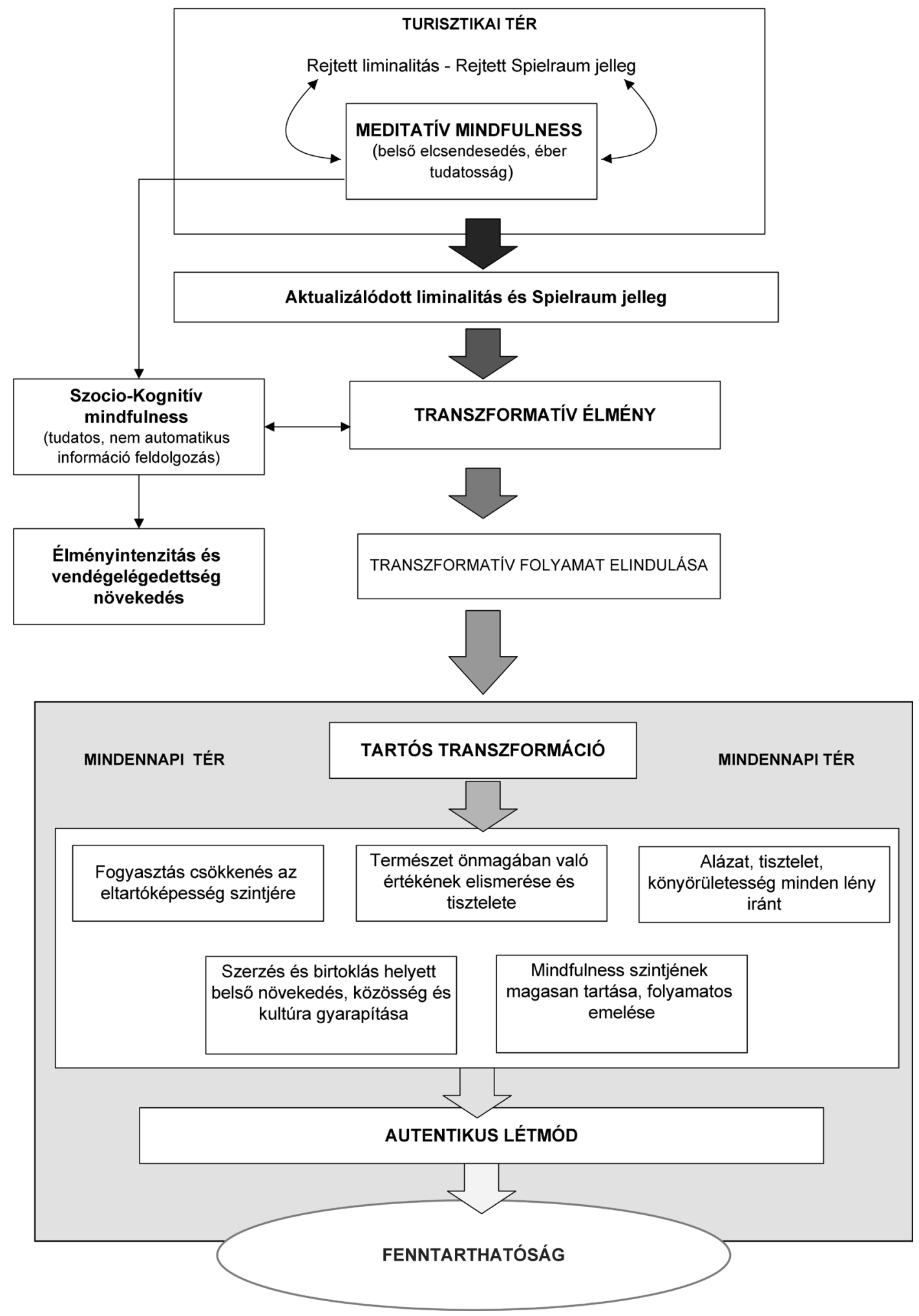

Forrás: saját szerkesztés 
transzformatív utazás" rossz dilemmája feloldható, és összeegyeztethetővé válik a kis távolságokat favorizáló fenntarthatóbb proximity turizmus (DUBOIS et al. 2011, JEURING-HAARTSEN 2017) és a turisztikai kontextusban indukált transzformáció igénye. A hétköznapokban is transzformálódott, a fogyasztói paradigma helyett spirituális alapokra helyezett életet élő ember egy idő után lehet, hogy nem fogja szükségét érezni az utazásnak, nem lesz szüksége a desztináció liminalitást indukáló „segítségére”. Számára a hétköznapi tér és minden banális cselekvés re-szakralizálódhat. Hogy ez hogyan hat vissza a SEK-ek hosszútávú gazdasági fenntarthatóságára egy olyan kérdés, ami szétfeszítené ennek a tanulmánynak a kereteit, ugyanakkor jövőbeni kutatásra érdemes.

A transzformáció (COGHLAN-WEILER 2018), akárcsak az autentikus lét (BROWN 2013), a turisztikai szakirodalomban túlhasznált és homályos fogalmak. A turisztikai kontextussal és az egyénnel összefüggésben eddig megfogalmazott transzformáció értelmezések nem, vagy csak nagyon limitáltan használhatóak egy olyan normatív, humán és ökoetikára alapuló megközelítésben, amely a fenntarthatóságot állítja a középpontba. Ennek legfőbb oka, a transzformáció irányultságának, más szóval a transzformáció morális, etikai mozzanatának a hiánya (KIRILLOVA et al. 2017a). Ezek a transzformáció értelmezések értéksemlegesek, a transzformáció nyomán előálló új én-koncepció, autentikus létmód morális-etikai értelemben bármit jelenthet. Ha pusztán az elméletalkotás logikai koherenciáját vesszük, akkor ezzel semmi gond, viszont a fenntarthatósági válság felől nézve egy értéksemleges transzformáció koncepció nem elégséges. Jelen írás azt az alapvetô világszemléleti és viselkedésbeli változást tekinti transzformációnak, melynek nyomán a szerzésre, birtoklásra, élvezetmaximalizálásra kondicionált, elidegenedett és egyre neurotikusabb posztmodern ember úgy alakul át, hogy:

- nem akar többet elvenni a természettől, mint amit annak eltartóképessége megenged;

- megérti, hogy a természet és az élőlények, őt magát és a többi embert is beleértve, egy csodálatosan összeszőtt egész részei, és az aktuális hasznosságukon túl belső értékkel bírnak;

- a kölcsönös függést és összekapcsoltságot felismerve, alázattal, tisztelettel és könyörületességgel fordul maga, társai és a többi élőlény felé;

- nem akar mások rovására gazdagodni, a növekedés elsődlegesen belsó növekedés, a gazdagodás elsôsorban a belsố értékeinek és a közösség értékeinek a gazdagítását jelenti;
- felismeri, hogy a mindfulness a spirituális lét alapja, és megpróbál állandóan éberen és tudatosan jelen lenni, így kerülve el, hogy a saját tudatalatti késztetései vagy a fogyasztói társadalom manipulatív erói irányítsák.

Ezt az öt feltételt nevezhetjük a fenntarthatóság-kompatibilis autentikus létmód minimumának (továbbiakban ALÉMI). Ezt a transzformációt a turisztikai tér liminalitása, a beavatásszerú élmény általában „csak” beindítja. A tartós átváltozás, a fenti szempontokat hétköznapokban érvényesítő, a fenntarthatóság szempontjából autentikusnak nevezhetô létmód kialakulása a hazatérés után valósulhat meg (KIRILLOVA et al. 2017a).

Az ALÉMI egyéni életben történó gyakorlati megvalósítása, nap mint nap történô átélése az, ami a fenntarthatóság szempontjából autentikus létmódnak nevezhetô. Ez a fajta definíció erősen normatív, túlmegy azon a posztmodern felfogáson, melyben az autentikus létmód mindenki számára szubjektíven más és más. Az autentikus lét tulajdonképpen egy érzés vagy csak egy fantázia (WANG 1999, KNUDSEN et al. 2016). Az 1. ábra foglalja össze a mindfulness turisztikai térben betöltött jelentőségét és az ebból eredő, a fenntarthatóságot érdemben befolyásolni képes hatásokat. Emellett a magas mindfulness szint a desztinációban szerzett élményekre, a desztinációhoz való viszonyulásra és a desztinációban mutatott viselkedésre is pozitív hatással van (LYNN et al. 2017).

\section{A Spirituális Elvonulási Központok tipológiája és célközönsége}

Ahogyan az elvonulási központoknak (retreat) általában, úgy a SEK-nek sem létezik egységes tipológiája és klasszifikációja a szakirodalomban, és értelemszerúen egységes definíció sincs. Jelen cikk klasszifikációjában az elvonulási központ (retreat) a legnagyobb halmaz, mely magába foglalja a SEKeket. Ez utóbbiak részhalmazát képezik azok a SEK-ek, melyek elsődlegesen az MM gyakorlatokra alapozzák múködésüket. KELLY (2012:205) következőképpen definiálja az elvonulási központokat: „Egy retreat sokféle jelentéssel birhat; lehet csendes reflexióra és visszafiatalodásra szolgáló hely, egy lehetôség az egészség visszanyerésére, és/vagy jelenthet egy olyan idősakot, mikor valaki egyedül csendesen vagy csoportban megpróbál spirituálisan megújulni és fejlődni." KELLY (2012) empirikus adatok alapján arra a következtetésre jut, miszerint az elvonulási központokon belül a SEK, holisztikus megközelítése miatt, határozottan elkülöníthetô a wellness szektor többi részétől. A különállás döntő momentuma 
Lektorált tanulmányok

KELLY (2012:211) szerint: „A legtöbb turizmusformától eltéróen a SEK kiprovokálja azt, hogy a látogatói reflektáljanak saját magukra a nyaralásuk alatt és után is ... kontextualizálják magukat annak megfelelóen, hogy éppen hol tartanak és hová szeretnének eljutni a saját életükben." Ez a megközelítés egybevág a jelen tanulmány SEK-re vonatkozó felfogásával. A SEK-en belül az MM-re épített elvonulási központok a legfontosabbak a cikk mondanivalója szempontjából. EDDY (2014:58) a következőt jegyzi meg egy MMre épülő meditációs központtal kapcsolatban: ,„... a felszinen mutatkozó hasonlóság ellenére az MM-re alapozott SEK-ek, mint különlegesen liminális helyek, jelentősen eltérnek a vallási turizmus olyan egyéb formáitól, mint például a zarándokturizmus, amire inkább a liminoid jelző a megfelelō." A liminoid élmények általában nem "küszöb-átlépő” (threshold-crossing) jellegúek, szemben a beavatás jellegú liminális tapasztalásokkal (TURNER 1974). A szerző értelmezése szerint a SEK-eket vallási vagy szekuláris kontextustól függetlenül általában, de nem szükségszerúen, összeköti a modern urbanizált léttól való távolságuk, valamint az a belső hazatalálás, belső transzformáció iránti igény, ami az ide érkező turistákat jellemzi (SMITH-KELLY 2006, SMITH-REISINGER 2013) és ami a tanulmány 3. fejezetének spiritualitás definíciójában már megjelent. A SEK-ek (HALL 2006) esetében a liminalitás és elvonulás három mélységi szinten, egyre erôsödôen jelenik meg. Az elsố szint az otthontól való eltávolodás a desztinációba való megérkezésig, ezt követi a desztináción belül a SEK-be történő visszavonulás, majd a végső és legmélyebb szint, a meditáció során a Jézus által „belső szobának” nevezett önvaló mélységeibe történô elvonulás (2. ábra). Az önvaló mélységeibe történő elvonulás megtörténhet egy sámán utazásokra, pszichoanalízisre vagy intenzív katolikus imádságra épüló SEK-ben is. Az MM-re épüló SEK esetében van egy lényeges és radikális mozzanata ennek a belsó szobába történô elvonulásnak, ami a többi SEK-re nem jellemzó. Ez a mozzanat az elengedés, mindennek (képek, fogalmak, érzések, vágyak, szenzoriális ingerek) az elengedése (HANH 2016). A buddhizmuson kívüli spirituális hagyományok még a legnagyobb elmélyülésben is ragaszkodnak valamilyen formához (például ima, vizualizáció). Az, hogy az első és második szint (2. ábra) liminális vagy liminoid tapasztalás, az egyén nyitottságától, mindfulness szintjétól és a helyzetek liminális potenciáljától függ.

Demográfiai profiljukat tekintve a tipikus SEK látogatók 45 év feletti, magasan képzett (egyetem), jól kereső, leginkább egyedül utazó nók (VOIGT et al. 2011). A spiritualitás iránt érdeklődő turisták push és pull motivációi sokfélék lehetnek (YOU et al. 2000, YOUSEFI-MARZUKI 2015). VOIGT és szerzôtársainak (2011) kutatásában a SEK-ek látogatóinak motivációi közül a legjelentósebb faktor a "transzcendencia”, melyhez olyan prioritások kapcsolódnak, mint a valódi én megtalálása, az önfelfedezés és megértés, a medi-

\section{Az elvonulás 3 szintje egy SEK esetén}

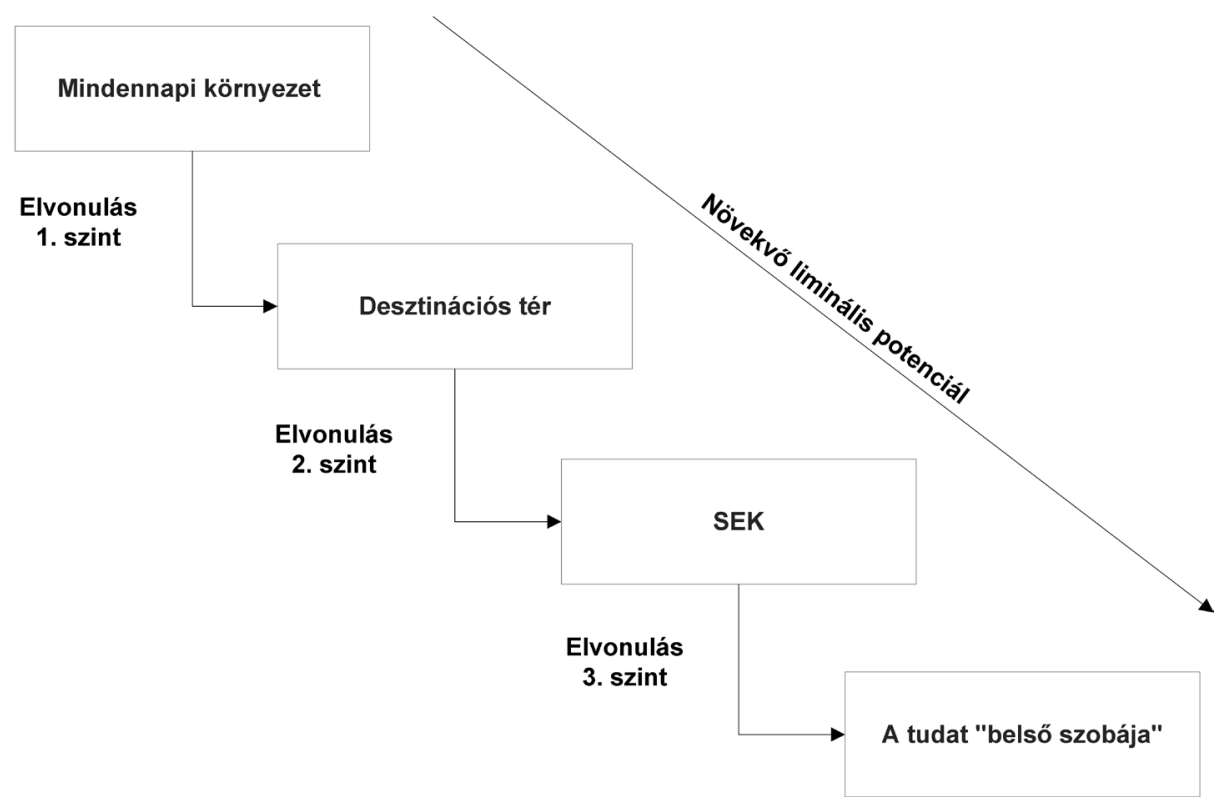

Forrás: saját szerkesztés 
tációs technikák tanulása és/vagy elmélyítése, a belső béke megtalálása, a nyugalom megtapasztalása, az élet értelmének megtalálása és az érzéki tapasztalás finomítása.

\section{5. Összefoglalás}

Jelen tanulmány egyik fó célja az volt, hogy ráirányítsa a figyelmet a spirituális elvonulási központokra (SEK-ek), melyek hatványozottan hordozzák azt a liminális/Spielraum potenciált, ami a turisztikai térnek általánosságban a sajátja. Ugyancsak szeretett volna rávilágítani arra, hogy mindfulness, tehát a tipikus posztmodern fogyasztói tudatállapottól gyökeresen különböző, belsố elvonulást és elcsendesedést kívánó tudatállapot, nélkül nem tud aktualizálódni a turisztikai tér liminalitása, nem tud transzformatív lenni az élmény, nem tud elindulni az a fajta átalakulás, ami a fenntarthatóság perspektivoájából autentikus létmódhoz vezetne. A humán és ökoetika fontosságát tevőlegesen hangsúlyozó (ALÉMI) SEK-ek, elsődlegesen azok MM-re alapozott típusai, olyan küldetést töltenek be, ami a desztinációt, a turizmust, annak tradicionálisan hedonikus mivoltán messze túlmutató dimenzióba emelik. A SEK-ben igénybevett MM-re alapozott szolgáltatások olyan hordozható turisztikai termékek, amik a mindennapi környezetben költségmentesen gyakorolhatók, és segítik szárba szökni a transzformáció desztinációban elvetett magvát. Az ALÉMI-hoz vezetô transzformáció nem elsősorban kognitív kihívás. Ha az lenne, az elmúlt hat évtized propagandája elég lett volna egy gyökeres változásra. A fenntarthatatlan fogyasztói paradigma, a fogyasztói gépezet az ember tudatalattijának, ösztöneinek és egojának a manipulációjára, a vágyak felkorbácsolására, és azok kielégítésének illúziójára épül. Mivel a mindfulness klinikai vizsgálatai igazolták, hogy akár pár napos intenzív MM tréning is jelentôs változásokat indukálhat (TANG et al. 2010), a desztináció liminalitását felerősítő SEK-ek kiemelten fontosak lehetnek ahhoz a belsố transzformációhoz, amely nélkül nem lehetséges az egyre fenntarthatatlanabb fogyasztói paradigma meghaladása. Bármi legyen is a posztmodern álláspont, a fenntarthatóság egy Nagy/ Meta narratíva, melynek fundamentumát a lokális igazságokon átíveló, alapkérdéseket érintő globális értékkonszenzus képezi. Az értékrendbeli és ebből következően életstílusbeli paradigmaváltás óriási egyéni és közösségi kihívás. Ezen kihívás megoldásában a SEK-eknek és a mindfulness-nek jelentős szerepe lehet.

Jelen cikk elsődlegesen a SEK-ek jelentőségének elméleti megalapozását próbálta elindítani. Ugyanakkor számos olyan kérdés vetődik fel, mely mind az elmélet, mind a gyakorlati megvalósíthatóság terén további kutatásra lehet érdemes. Kérdésként merül fel például, hogy milyen belső motivációkkal bír a SEK-ek potenciális hazai célközönsége? Ha elfogadjuk, hogy nagy tömegeknek kellene minél gyorsabban világszemléletet és erre alapulva életstílust váltani, akkor kérdés az is, hogy milyen szerepe lehet a SEK-ek létrehozásában, népszerúsítésében és hozzáférhetőségében a mindenkori kormányzatoknak (MAPPG 2015, HYLAND 2016), a vallási, spirituális szervezeteknek és tanítóknak (OSHO 2008). Kutatás tárgya lehet, hogy milyen interakció van a belső motivációk és az előzó mondatban említett külsô motivációk között? Nincsenek sem külföldi, sem hazai empirikus kutatások arról, hogy a bizonyíthatóan a desztinációban indukált és az otthoni környezetben végigmenó belső transzformációknak milyen fenntarthatósági hozadéka van. A tanulmányban korábban kérdésként merült fel, hogyan egyeztethető össze a nagy távolságú, transzformatív célból történô utazás a fenntarthatósággal, illetve a proximity turizmus a transzformativitásra irányuló igénnyel.

\section{Köszönetnyilvánítás}

Köszönettel tartozom a kutatás támogatásáért, amely az EFOP-3.6.1-16-2016-00006 „A kutatási potenciál fejlesztése és bővítése a Neumann János Egyetem" pályázat keretében valósult meg. A projekt a Magyar Állam és az Európai Unió támogatásával, az Európai Szociális Alap társfinanszírozásával, a Széchenyi 2020 program keretében valósul meg.

\section{Felhasznált irodalom}

ANDREWS, H. - ROBERTS, L. (eds) (2012): Liminal landscapes: Travel, experience and spaces in-between. Routledge.

BHIKKHU, B. - POTPARIC, O. - BUDDHA, G. (1995): The Middle Length Discourses of the Buddha: A Translation of the Majjhima Nikaya (No. 49). Simon and Schuster.

BROWN, K. W. - RYAN, R. M. (2003): The benefits of being present: mindfulness and its role in psychological well-being. Journal of personality and social psychology. 84(4). 822-848.

BROWN, L. (2013): Tourism: A catalyst for existential authenticity. Annals of Tourism Research. 40. pp. 176-190.

BÜSCHER, B. - FLETCHER, R. (2017): Destructive creation: Capital accumulation and the structural violence of tourism. Journal of Sustainable Tourism. 25(5). pp. 651-667. 
CHAN, E. Y. (2018): Mindfulness promotes sustainable tourism: the case of Uluru. Current Issues in Tourism. pp. 1-5.

COGHLAN, A. - WEILER, B. (2018): Examining transformative processes in volunteer tourism. Current Issues in Tourism. 21(5). pp. 567-582.

DANN, G. M. (1996): Tourists' images of a destination-an alternative analysis. Journal of Travel $\mathcal{E}$ Tourism Marketing. 5(1-2). pp. 41-55.

DÁVID, L. (2011): Tourism ecology: towards the responsible, sustainable tourism future. Worldwide Hospitality and Tourism Themes. 3(3). pp. 210-216.

DAVIS, D. M. - HAYES, J. A. (2011): What are the benefits of mindfulness? A practice review of psychotherapy-related research. Psychotherapy. 48(2). pp. 198-208.

DE VIBE, M. F. - BJØRNDAL, A. - FATTAH, S. DYRDAL, G. M. - HALLAND, E. - TANNERSMITH, E. E. (2017): Mindfulness-based stress reduction (MBSR) for improving health, quality of life and social functioning in adults: a systematic review and meta-analysis. Campbell Systematic Reviews.

DIENER, E. - LUCAS, R. E. - SCOLLON, C. N. (2009): Beyond the hedonic treadmill: Revising the adaptation theory of well-being. In: Diener, E. (ed): The Science of Well-Being. Springer, Dordrecht. pp. 103-118.

DUBOIS, G. - CERON, J. P. (2006): Tourism and climate change: Proposals for a research agenda. Journal of Sustainable Tourism. 14(4). pp. 399-415.

DUBOIS, G. - PEETERS, P. - CERON, J. P. GÖSSLING, S. (2011): The future tourism mobility of the world population: Emission growth versus climate policy. Transportation Research Part A: Policy and Practice. 45(10). pp. 1031-1042.

EDDY, G. (2014): The Vipassana retreat experience: A consideration of the meditation retreat as a religious paradigm of travel. Literature $\mathcal{E}$ Aesthetics. 22(1). pp. 38-59.

EIFRING, H. (2013): Meditation in Judaism, Christianity and Islam: Technical Aspects of Devotional Practices. Meditation in Judaism, Christianity and Islam: Cultural Histories. pp. 1-13.

FRAUMAN, E. - NORMAN, W. C. (2004): Mindfulness as a tool for managing visitors to tourism destinations. Journal of Travel Research. 42(4). pp. 381-389.

GIFFORD, R. (2011): The dragons of inaction: psychological barriers that limit climate change mitigation and adaptation. American Psychologist. 66(4). pp. 290-302.

GÖSSLING, S. - PEETERS, P. (2007): 'It does not harm the environment!'An analysis of industry discourses on tourism, air travel and the en- vironment. Journal of Sustainable Tourism. 15(4). pp. 402-417.

HALL, C. M. (2006): Buddhism, tourism and the middle way. In: Timothy, D. J. - Olsen, D. H. (eds): Tourism, religion and spiritual journeys. pp. 172-185.

HANH, T. N. (2016): The miracle of mindfulness: An introduction to the practice of meditation. Beacon Press.

HEIDEGGER, M. (1962): Being and time. New York: Harper \& Row.

HEINTZMAN, P. (2013): Retreat Tourism as a Form of Transformational Tourism. In: Reisinger, Y. (ed): Transformative tourism: tourist perspectives. Wallingford: CABI. pp. 68-81.

HOLZ, C. - KARTHA, S. - ATHANASIOU, T. (2018): Fairly sharing 1.5: National fair shares of a 1.5 C-compliant global mitigation effort. International Environmental Agreements: Politics, Law and Economics. 18(1). pp. 117-134.

HYLAND, T. (2016): Mindful nation UK - report by the mindfulness all-party parliamentary group (MAPPG). https://www.researchgate. net/publication/289500681_Mindful_Nation_ UK_-_Report_by_the_Mindfulness_All-Party_ Parliamentary_Group_MAPPG Letöltve: 2019. március 5.

JAIMANGAL-JONES, D. - PRITCHARD, A. MORGAN, N. (2010): Going the distance: locating journey, liminality and rites of passage in dance music experiences. Leisure Studies. 29(3). pp. 253-268.

JEURING, J. H. G. - HAARTSEN, T. (2017): The challenge of proximity: the (un) attractiveness of near-home tourism destinations. Tourism Geographies. 19(1). pp. 118-141.

KELLY, C. (2012): Wellness tourism: Retreat visitor motivations and experiences. Tourism recreation research. 37(3). pp. 205- 213.

KIRILLOVA, K. - LEHTO, X. - CAI, L. (2017a): Tourism and Existential Transformation: An Empirical Investigation. Journal of Travel Research. 56(5). pp. 638-650.

KIRILLOVA, K. - LEHTO, X. - CAI, L. (2017b): What triggers transformative tourism experiences? Tourism Recreation Research. 42(4). pp. 498-511.

KNUDSEN, D. C. - RICKLY, J. M. - VIDON, E. S. (2016): The fantasy of authenticity: Touring with Lacan. Annals of Tourism Research. 58. pp. 33-45.

LANGER, E. J. - BLANK, A. - CHANOWITZ, B. (1978): The mindlessness of ostensibly thoughtful action: The role of" placebic" information in interpersonal interaction. Journal of personality and social psychology. 36(6). pp. 635-642. 
LANGER, E. J. (1989): Minding matters: The consequences of mindlessness-mindfulness. Advances in experimental social psychology. 22. pp. 137-173.

LANGER, E. J. (1993): A mindful education. Educational Psychologist. 28(1). 43-50.

LÁNYI A. (2013): Morális klímaváltozás. Magyar tudomány. 7. pp. 822-829.

LENGYEL A. (2015): Mindfulness and sustainability: Utilizing the tourism context. Journal of Sustainable Development. 8(9). pp. 35-51.

LENGYEL A. (2017): A Figyelem és Tudatosság Mindfulness Skála (FTMS) pilot tesztelése. Mentálhigiéné és pszichoszomatika. 18(4). pp. 334364.

LENGYEL A. (2018): A fenntarthatóság, mindfulness és turizmus tértudományi összefüggései. Doktori (PhD) értekezés. Szent István Egyetem, Enyedi György Regionális Tudományok Doktori Iskola, Gödöllő.

LENZEN, M. - SUN, Y. Y. - FATURAY, F. - TING, Y. P. - GESCHKE, A. - MALIK, A. (2018): The carbon footprint of global tourism. Nature Climate Change. 8(6). pp. 522-528.

LYNN, I. - CHEN, L. - SCOTT, N. BENCKENDORFF, P. (2017): Mindful tourist experiences: A Buddhist perspective. Annals of Tourism Research. 64. pp. 1-12.

MAGYAR BIBLIATÁRSULAT (2018): Szent Biblia. Károli fordítás.

MAPPG (2015): Mindful Nation UK. The Mindfulness Initiative. Report by the Mindfulness All-Party Parliamentary Group. London. https://themindfulnessinitiative. org.uk/images/reports/Mindfulness-APPGReport_Mindful-Nation-UK_Oct2015.pdf Letöltve: 2019. március 5.

MARTOS T. (2010): Életcélok és lelki egészség a magyar társadalomban. Doktori (PhD) értekezés. Semmelweis Egyetem, Mentális Egészségtudományok Doktori Iskola, Budapest.

MERTON, T. (1999): Mystics and Zen masters. Farrar, Straus and Giroux.

MITEV A. - IRIMIÁS A. R. - MICHALKÓ G. (2017): Rítusba oltott átalakulás: transzformáció a vallási turizmusban. In: Régi T. - Rátz T. - Michalkó G. (szerk.): Turizmus és transzformáció. Turizmus Akadémia 8. Kodolányi János Főiskola- MTA CSFK Földrajztudományi Intézet- Magyar Földrajzi Társaság, OrosházaBudapest. pp. 37-50.

MOSCARDO, G. (1996): Mindful visitors: Heritage and tourism. Annals of tourism research. 23(2). pp. 376-397.

OBINYAN, V. E. (2014): Nature of human existence in Kierkegaard's ethical philosophy: A step towards self-valuation and transformation in our contemporary world. International Journal of Philosophy. 2(1). pp. 1-14.

OSHO, B. R. (2008): Glimpses of a golden childhood (Talks given from 1984). Rebel Publishing House.

PIYADASSI, T. (1998): The Buddha: His Life and Teachings. Buddhist Publication Society.

PRITCHARD, A. - MORGAN, N. (2006): Hotel Babylon? Exploring hotels as liminal sites of transition and transgression. Tourism Management. 27(5). pp. 762-772.

RÉGI T. - RÁTZ T. - MICHALKÓ G. (2017): Turizmus és transzformáció. Turizmus Akadémia 8. Kodolányi János Fóiskola- MTA CSFK Földrajztudományi Intézet- Magyar Földrajzi Társaság, Orosháza-Budapest.

REISINGER, Y. (ed) (2013): Transformational tourism: Tourist perspectives. CABI.

ROHR, R. (2012): Immortal diamond: The search for our true self. John Wiley \& Sons.

SHUTT, H. (1998): The trouble with capitalism: An enquiry into the causes of global economic failure. Zed Books.

SMITH, M. - KELLY, C. (2006): Holistic tourism: Journeys of the self? Tourism Recreation Research. 31(1). pp. 15-24.

SMITH, M. - REISINGER, Y. (2013): Transforming quality of life through wellness tourism. Transformational tourism: Tourist perspectives. pp. 55-67.

STEINER, C. J. - REISINGER, Y. (2006): Understanding existential authenticity. Annals of Tourism Research. 33(2). pp. 299-318.

TANG, Y. Y. - LU, Q. - GENG, X. - STEIN, E. A. - YANG, Y. - POSNER, M. I. (2010): Short-term meditation induces white matter changes in the anterior cingulate. Proceedings of the National Academy of Sciences. 107(35). pp. 15649-15652.

TEASDALE, W. (2010): The mystic heart: Discovering a universal spirituality in the world's religions. New World Library.

TURNER, V. (1974): Liminal to liminoid, in play, flow, and ritual: an essay in comparative symbology. The Rice University Studies. 60(3). pp. 53-92.

VIDON, E. S. - RICKLY, J. M. (2018): Alienation and anxiety in tourism motivation. Annals of Tourism Research. 69. pp. 65-75.

VOIGT, C. - BROWN, G. - HOWAT, G. (2011): Wellness tourists: in search of transformation. Tourism Review. 66(1/2). pp. 16-30.

WAMSLER, C. - BRINK, E. (2018): Mindsets for Sustainability: Exploring the Link Between Mindfulness and Sustainable Climate Adaptation. Ecological Economics. 151. pp. 55-61. 
WANG, N. (1999): Rethinking authenticity in tourism experience. Annals of tourism research. 26(2). pp. 349-370.

WRATHALL, M. A. (ed) (2013): The Cambridge Companion to Heidegger's Being and Time. Cambridge University Press.

YOU, X. - O'LEARY, J. - MORRISON, A. - HONG, G. S. (2000): A cross-cultural comparison of travel push and pull factors: United Kingdom vs. Japan. International Journal of Hospitality $\mathcal{E}$ Tourism Administration. 1(2). pp. 1-26.
YOUSEFI, M. - MARZUKI, A. (2015): An analysis of push and pull motivational factors of international tourists to Penang, Malaysia. International Journal of Hospitality $\mathcal{E}$ Tourism Administration. 16(1). pp. 40-56.

ZSOLNAI L. (2010): Boldogság és gazdaság: A buddhista közgazdaságtan eszméi. Typotex, Budapest. pp. 8-25.

\section{Internetes forrás}

Online etymology dictionary: www.etymonline.com 